\title{
Implementation of Problem Posing Learning on Conceptual Understanding and Adaptive Reasoning
}

\author{
Eko Putro Andi Setiawan, Eko Putro A.S, Tatag Yuli E.S, Rooselyna Ekawati \\ Universitas Negeri Surabaya \\ Surabaya, Indonesia \\ ekosetiawan16070855088@mhs.unesa.ac.id
}

\begin{abstract}
This research is based on the low level of students' mathematical skills in elementary schools, including conceptual understanding and adaptive reasoning. So it takes learning that emphasizes the conceptual understanding and adaptive reasoning is learning problem posing. This study uses Quasi Eksperimen. In the experimental group used problem posing learning with winger application, while in the control class used STAD learning assisted wingeom application. The results showed that learning posing problems with wingeom application support can improve conceptual understanding and thinking in adaptive reasoning in solving various mathematical problems, especially geometric math problems.
\end{abstract}

Keywords-Problem posing; mathematical skills; geometry

\section{INTRODUCTION}

Education in Elementary School is an early stage to continue learning to the next level of higher, and also a provision of life when socializing in the community. Therefore, education in elementary schools allegedly has not indicated the direction of independent learning that can make the students aware that the nature of him studying in school is as initial capital in the community. In this case, the school as the implementer of education is very influential and of course the mainland as the target of all parties both parents, community and bureaucratic ranks also get the impact directly. In addition, the teacher also plays an important role in learning in the school, therefore required an optimal learning process and conducive. In the process of learning, a teacher needs to condition the classroom to be conducive, so that will increase student activity high and optimal learning outcomes.

Mathematics can be said as a symbol or a means of communication because in mathematics there are many of the same symbols but have different meanings. In the current 2013 curriculum, these math subjects have been separated by other subjects commonly referred to as thematic. Thus, in the course of learning mathematics is stand-alone is not integrated by other subjects. At the end of each lesson, a teacher must provide a task-shaped evaluation so that the teacher knows how the learners' response to the learning that has been delivered. A teacher will definitely provide an evaluation to the learners because the ultimate goal of a learning is that learners understand and understand so that one day it can solve the problem at hand.

Mathematics is a basic science that must be accepted by all levels of education because mathematics has a role in the formation of the mindset held by learners so that learners are able to think critically, logically, and creatively. In mathematics is often done an improvement and change that can improve the quality of learning so that mathematics can follow the information technology and answer the demands of the world. Mathematics is one of the subjects that support education and should be delivered in elementary school, this is because mathematics has an important role in the life of society because of its universal and comprehensive so that it can be used in all areas.

In Mathematics there is a mathematical proficiency which includes five components according to [1], namely: (1) conceptual understanding; (2)procedural fluency; (3)strategic competence; (4)adaptive reasoning; and (5)productive disposition. These components should be developed in an integrated and balanced way in students who learn math [2]. The five components of the mathematical prowess are not mutually exclusive but intertwined into one. The fifth development of the students also cannot be done separately. Mathematics subject matter according to Curriculum 2006 (BSNP, 98) covers the following aspects: number, geometry, measurement and data processing.

Based on the experience of researchers during teaching at the elementary school Siti Aminah, mathematics learning has not yet achieved the overall mathematical skills. Students are still accustomed and dependent on the material presented by the teacher so that students still often forget about the material presented and seem still confused if the math problems discussed are not familiar with the students' daily life, so in the mathematics learning, the evaluation given is not just the numbers which are calculated in value but there are also sentences arranged in such a way that learners not only calculate the magnitude of the numbers but also understand the purpose of the sentence. Such an evaluation is commonly known as a story. The story is a matter in mathematics that links learning materials to everyday life. The ability of 
learners in solving the problem of different stories because students must use some of his skills in solving the story. The initial ability that must be possessed by the learner before solving the story problem is the student's ability to answer the questions given by the teacher correctly, the students dare to express their thoughts or opinions in the learning process, and the students are able to understand and conclude the material given by the teacher.

One of the models of mathematics learning that can be applied by teachers in solving a problem is the model of learning problem posing. Problem posing is considered appropriate to achieve and improve the ability of mathematical skills, this is because the problem posing is a learning activity where a learner participate in the process of making the story and able to solve it in accordance with the theory or material that has been studied. This model problem posing is in line with the objectives of the 2013 curriculum in which learners play an active role in the learning process in the classroom. This learning model can hone the ability of students' mathematical skills to improve conceptual understanding and adaptive reasoning.

In practice, teachers should use strategies and teaching models that require students to be active in learning both mentally, physically and socially. According to Taker [3] students' active role in constructing their knowledge as meaningful as they can which means students must play an active role in building their knowledge as much as possible in order for them to gain meaningful learning. For that effort to improve learning more done by teachers in carrying out their duties and responsibilities as educators and teachers. The teaching model is a teaching plan that describes the process undertaken in the learning process in order to achieve specific changes in the student as expected. By using the right learning model can help the implementation of teacher tasks in the process of teaching and learn in the classroom. Teachers can develop teaching models that are deemed to fit the objectives, materials, and support facilities in carrying out teacher teaching tasks.

In the process of learning problem posing, learning begins with the filing of problems or questions of learners based on existing information. In the implementation of learning it helps learners in formulating a problem based on the topic or material that the teacher has explained so that it is more deeply accompanied by its solution [4]Problem posing can be done individually or in groups, as both contribute to the understanding of learners. In groups, can establish mutually beneficial cooperation and can develop rational ability problems because learners can discuss with a group of friends. Individually, submission of questions can help students be more independent and active in learning, the questions posed individually have the opportunity to be solved first thought through carefully and earnestly so that this will optimize the student learning outcomes. Problem Posing Learning model has some advantages such as can increase student activity so that more active in learning, not easy to despair, confident and have thought of solving a problem. In the implementation can be associated with various interactive media learning in accordance with the purpose of learning mathematics in mastering the ability of mathematical skills, one of which is wingeom, an application requires students to further develop the ability of mathematical skills in particular material geometry. The use of simple media that requires students to find their own concepts contained in geometry so that children better understand the material being taught.

\section{METHOD}

The research design that will be used is quasiexperiment. The approach used in this study is a quantitative approach descriptive because in this study using data in the form of numbers and data processing done by statistical calculations. With the research to be done is nonequivalent control group design. According to [5] nonequivalent control group design that is, two existing pretest groups, administered a treatment, and post-tested. Here is a design that can be described as follows:
$\mathbf{O}_{1}$
$\mathbf{X}$
$\mathbf{O}_{2}$

$\mathbf{O}_{3}$

$\mathbf{O}_{4}$

\section{Description:}

O1 and O3: Initial test (pre-test), before being treated.

O2: Final test (post-test), experimental / treatment group results, given after treatment

O4: post-test, results from an untreated control group

$\mathrm{X}$ : Treatment using a learning model Comparison of $\mathrm{N}$ - gain from $(\mathrm{O} 2 \neg-\mathrm{O} 1)$ of $\mathrm{N}$-gain from (O4- O3).

This research was conducted at SD Siti Aminah in academic year 2017/2018. Classes used as an experimental class are VA consisting of 34 students, 14 male students, and 20 female students and VB class as a control class consisting of 34 students, 19 male students, and 15 female students.

The validity test uses the correlation technique product moment because the form of the test is a Content objectively. If the value of significance obtained $\leq 0.05$ then the item can be said to be valid. The formulation of the coherent Biser's coefficient is as follows:

$$
r_{x y}=\frac{N \sum X Y-\left(\sum X\right)\left(\sum Y\right)}{\sqrt{\left.\left(N \sum X^{2}-\left(\sum X^{2}\right)\right\} N \sum Y^{2}-\left(\sum Y^{2}\right)\right\}}}
$$

Description:

$r_{x y}=$ Validity of test items

$\mathrm{N}=$ Number of students

$\mathrm{X}=$ Scores of participants on the items to be searched for validity 
$\mathrm{Y}=$ Total score achieved by learners

The t-test is used to verify whether the hypothesis is accepted or not. The formula used in this study is the t-test. If $\mathrm{T}_{\text {arithmetic }} \leq \mathrm{T}_{\text {able, }}$, then Ha accepted and Ho rejected and if If $\mathrm{T}_{\text {arithmetic }}>\mathrm{T}_{\text {able, }}$, then Ho accepted and Ha rejected Since the number of $\mathrm{n}_{1}$ and $\mathrm{n}_{2}$ is not the same, then used the t-test formula for the polled variance sample as follows:

$t-$ test $=\frac{X_{1}-X_{2}}{\sqrt{\frac{\left(n_{1}-1\right) s_{1}^{2}+\left(n_{2}-1\right) s_{2}^{2}}{n_{1}+n_{2}-2}\left(\frac{1}{n_{1}}+\frac{1}{n_{2}}\right)}}$

Information:

$X_{I} \quad=$ Average $=$ mean of treatment sample $($ sample 1$)$

$X_{2} \quad=$ Average $=$ mean of treatment sample (sample 2$)$

$S \quad=$ Standard deviation (Standard deviation)

$n 1 \quad=$ Number of control respondents

$n 2 \quad=$ Number of respondents of the experimental group

\section{RESULTS AND DISCUSSION}

This research aims to improve the mathematical ability to use problem posing. Learning result data can be obtained from the results of values pretest and post-test in the control class and experimental class. The result of pretest and post-test is done with the aim to know the level of mathematical ability of students in learning. The average comparison of the value results of the two classes will be indicated by the following diagram.

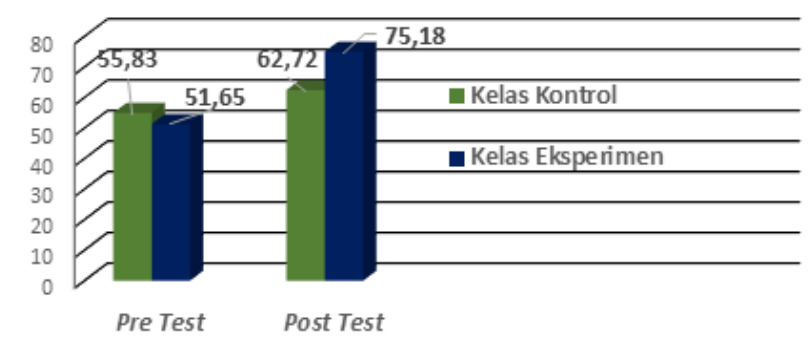

TABLE PRE TEST AND POST TEST

In the test t-test with SPSS assistance calculation Statistic 21 , at the $5 \%$ level, $=\mathrm{t}_{0.05}$ because at the $5 \%$ level as a significant level for obtaining the result determines the likelihood of making the risk of error making the decision to reject the hypothesis correctly (Siregar, $2103: 41$ ), aimed at whether the media used influenced the students' learning outcomes. Previously looking for a differentiator from pretest and posttest control classes and experimental classes then input data with the help of SPSS Statistic 21. Here is the result of t-test test.
TABEL 4.8

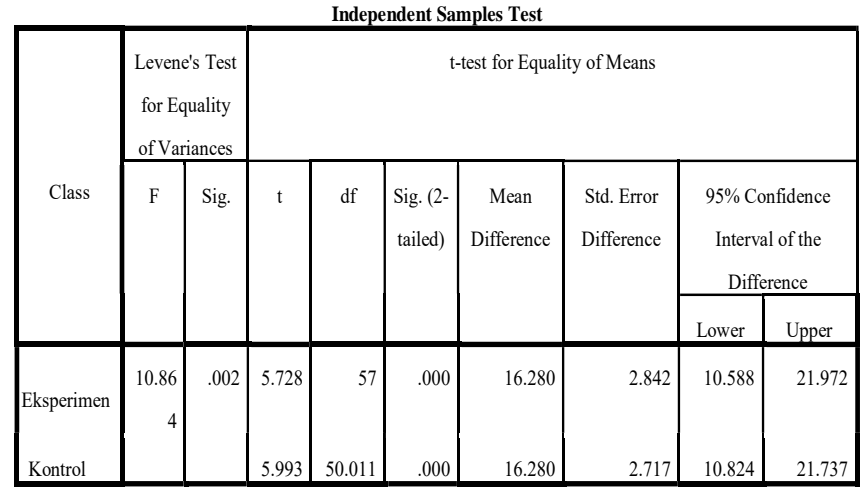

Uji t-test based on the calculation of t-test tested by SPSS Statistic 21, if a significant level below 0.05 it means that there is an influence. Based on the t-test conducted by Sig. (2-tailed) with significant value 0,000 , it can be concluded that $\mathrm{Ha}$ accepted and Ho rejected, the influence of using problem posing model to the improvement of mathematical ability.

\section{CONCLUSION}

Model Learning used is Problem Posing. Based on the results obtained in this study. In the calculation of t-test test with the help of SPSS Statistic 21 obtained the result on Sig. (2-tailed) with significant value that is $0.00<0.05$ then it can be concluded that Ha accepted and Ho rejected. In the experimental class, the result of the test score gain score of 0.94 is included in the high category $(0.70 \leq 0.94)$ with the high category. Based on the results obtained calculations, it means there is a significant influence from the use of problem posing model of VA class experimental class at SD Siti Aminah Surabaya.

\section{REFERENCES}

[1] J. Kilpatrick, "Understanding mathematical literacy: The contribution of research. Educational studies in mathematics," 2001.

[2] K. Widjajanti, "Model pemberdayaan masyarakat," 2011.

[3] F. dkk Maonde, AplikasiPenelitian Eksperimen dalam bidang Pendidikan dan Sosial. Kendari: Unhalu Press, 2015.

[4] M. Thobroni, Belajar \& Pembelajaran Teori dan Praktik. Yogyakarta: Ar-Ruzz Media, 2015.

[5] H. Darmadi, Metode Penelitian Pendidikan. Bandung: Alfabeta, 2011.

[6] Suharsimi, Arikunto. Prosedur Penelitian Suatu Pendekatan Praktik. Rineka Cipta. Jakarta, 2010.

[7] A.A. Carin. Teaching Modern Science. Six Edition New York: Macmillan Publishing Company. 1993. 
[8] R.W. Dahar. Teori-Teori Belajar dan Pembelajaran. Jakarta:Erlangga. 2011.

[9] Depdiknas, Pembelajaran Tuntas, Jakarta, Direktorat Pembinaan Sekolah Menengah Atas, Dikdasmen,2008.

[10] Li-Shu, Lu, dkk, A study Curriculum Structure and Industry Needs for Digital Media Design Education in Taiwan, hal 895-899, 2013.

[11] Maonde, Faad dkk,AplikasiPenelitian Eksperimen dalam bidang Pendidikan dan Sosial. Kendari: Unhalu Press, 2015.

[12] S. Ucusa, Elementary School Teachers' Views on Game-based Learning as a Teaching Method, hal. 401-409, 2015.

[13] Usman, M. Uzer, Statistik Dalam Penelitian Psikologi Dan Pendidikan. Malang: UMM Press, 2009.

[14] Winarsunu, T, Statistik dalam Penelitian Psikologi dan Pendidikan. Edisi Revisi. Malang: UMM Press Malang, 2012.

[15] M. Yamin, Strategi Dan Metode Dalam Model Pembelajaran. Jakarta: Gaung Persada, 2007. 